\title{
Application of Information and Communication Technologies in Training of Criminal Analysts for the Units of the National Police of Ukraine
}

\author{
Anatolii Movchan ${ }^{1 *}$ [0000-0002-6997-6517], Maksym Movchan 2 [0000-0002-2099-3981] \\ ${ }^{1}$ Lviv State University of Internal Affairs, Lviv, Ukraine \\ ${ }^{2}$ National Police of Ukraine, Kyiv, Ukraine \\ *movchan.anatol@gmail.com
}

\begin{abstract}
Paper analyzes the system of training of criminal analysts for analytical units of the National Police of Ukraine. The priority directions of an improvement of training are determined, namely: conduction of trainings for criminal analysts, application of information technologies in training of specialists in criminal analysis, improvement of organization of an independent training of specialists. It is noted, that the information technology of teaching - innovative one, which involves the use of software and technical tools in work with information in the educational process, is a significant factor in the training of criminal analysts. The peculiarities of use of information technologies in training of criminal analysts, in particular the e-manuals and implementation of the electronic training course are considered. The emphasis is done on the use of programmable learning tools in the process of training of future criminal analysts in the following areas: teacher-consultant, hypermedia training system, quasi-teacher, virtual reality / virtual learning environment. It is emphasized that the creation of a virtual learning environment is possible only under conditions of a higher education institution, where there is an extended network of information that reflects the specificity and takes into account the peculiarities of training of specialists in criminal analysis. It was under lined that the priorities in the organization of training of specialists in criminal analysis in the centers of primary training "Police Academy" and higher education institutions of the Ministry of Internal Affairs of Ukraine should be: extensive use in the educational process of computer oriented tools along with information and communication technologies, practical application of distance learning technologies etc.
\end{abstract}

Keywords: Intelligence-Led Policing, criminal analysis, training, information and communication technologies, e-manual, virtual learning environment.

\section{INTRODUCTION}

The European Union Advisory Mission (EUAM) in Ukraine supports the Ministry of Internal Affairs and the National Police of Ukraine in order to implement the Intelligence-Led Policing / ILP - police-intelligence model in Ukraine in order to improve analytical capabilities of the National Police. The ILP is a model of police activity, due to which operational and analytical information / intelligence is used as the basis for conducting operations / investigations, and not vice versa. This model allows to reduce material means, the level of crime, provide a higher level of personnel security [1, p. 435; 2; 3].
Among all existing methods for analyzing operational information, adopted by law enforcement agencies in most developed countries, the most commonly used are software IBM i2 ANB and Anacapa.

Appropriate methods of applying criminal analysis for a long time have been used in the activities of law enforcement agencies of the European Union, the United States, Canada, as well as Interpol and Europol. In particular, analytical work uses operational, tactical, strategic analysis, open source data analysis and multisource analysis (Multi-Source Analysis) [4; 5].

In the system of the National Police of Ukraine during 2014-2016 a pilot project on the work of the Department 
for Combating Human Trafficking, Criminal Analysis and Risk Analysis Systems has been launched, which has contributed to the improvement of the effectiveness of investigating crimes related to human trafficking [6]. In 2017, the Office of Criminal Analysis of the National Police and relevant structural units in the regions were founded, which conditioned the task of completing these units by trained specialists.

At present, the professional level of National Police analytical staff is n't yet fully in line with ILP requirements. In addition, the training of criminal analysts is not always based on the use of modern information and communication technologies (ICTs).

Consequently, the implementation of a model of police activity, managed by analytics in the National Police needs to improve the system of training of criminal analysts, possessing both legal and special knowledge in the field of ICT. At the same time, analytical work is needed not only for the employees of the criminal analysis units, but also for all employees of the operational units and investigators.

Several aspects of the training of criminal analysts for law enforcement units were investigated by O.S. Adewale, O. K. Boyinbode, S. M. Gayadeen, Fr. Wesslau, G. Carter, O. Ye. Korystin, S. M. Kniaziev, Y. Liu, V. I. Melnyk, Ud. Moeller, V. A. Nekrasov, E. A. Salako, S. W. Phillips, I.H. Khan, X. Zhang and others.

In particular, the main areas of research are:

- problems of implementation of the model of policing activity guided by the analytics in law enforcement bodies [1];

- peculiarities of trainings and introduction of unified criminal analysis programs in educational process of institutions of higher education [2];

- the necessity of introducing a new model of training of employees of the criminal bloc of the National Police of Ukraine [7];

- definition of the main tasks of the criminal analysts of the Office of Criminal Analysis of the National Police [8];

- use of multimedia technologies to improve the learning process [9];

- evaluation of the results of studying academic disciplines $[10 ; 11]$.

However, in these studies, there are no approaches to the determination of the priority areas for the training of criminal analysts and the use of ICT in the training of specialists in criminal analysis.

One of the topical issues of training of specialists in criminal analysis is the use of ICT in the training of criminal analysts. Practical classes and trainings require the use of not only sufficient modern computer equipment and specialized software products, but also the introduction of information technology training, in particular, electronic manuals and e-learning courses, special computer programs and computer tests.

Taking into account the above mentioned, the purpose of this paper is to study the main areas of use of information and communication technologies in the training of specialists in criminal analysis for the units of the National Police of Ukraine.

\section{METHODOLOGY OF RESEARCH}

To accomplish the tasks of our study, several methods have been used: empirical - in an experimental study; theoretical - for the study and analysis of scientific, scientific and methodological literature, manuals, educational programs, generalization of information for the definition of theoretical and methodological grounds of the study.

\section{RESULTS AND DISCUSSION}

\subsection{General principles of the use of information and communication technologies in the training of specialists in criminal analysis}

Today information is becoming one of the most important resources in the educational process of the advanced countries all over the world. In order to ensure the integration of Ukraine's education system into the European and world educational space, decisive steps must be taken to modernize the target, content and technological aspects of education, based on the wide spread use of ICT [12].

In the course of the survey, we interviewed 160 practitioners of the analytical, operational and investigation units of the National Police. According to the results of the survey, the priority directions of an improvement of the training of specialists in criminal analysis were determined.

As we see, respondents in the priority areas of improving the training of specialists in criminal analysis include conducting trainings for criminal analysts (75\%), the use of information technology in the training of specialists in criminal analysis $(65 \%)$, improvement of the organization of independent training of specialists with the ability to use Internet resources $(57 \%)$.

The subjects of training of specialists in criminal analysis are: scientific and pedagogical employees; students of the centers of primary training "Police Academy", students of advanced training courses and cadets of the institutions of higher education of the Ministry of Internal Affairs; practical employees of the analytical units of the criminal police, involved in the educational process in educational and professional, educational programs; other employees of the institutions of higher education of the Ministry of Internal Affairs of Ukraine. 
The content of training of specialists in criminal analysis is determined by: the National Qualifications Framework; standards of higher and professional (professional and technical) education; educational and professional programs; work training programs; curricula; plans of practical, seminar and laboratory classes; practice programs.

Training of future specialists in criminal analysis is based on the principles of systematicity, scientific development, practical orientation, technological effectiveness, innovativeness.

The use of information technology in the training of criminal analysts involves the use of:

- cloud-oriented infrastructure:

- protected local network, Internet, Wi-Fi;

- servers with virtualization and clustering technologies;

- databases;

- computer laboratories;

- software and technological support:

- analytical software (i2 Analyst's Notebook, ANACAPA, ArcGIS, E-Gis maps, etc.);

- software of data management (MEMEX);

- automated information and retrieval systems of the Ministry of Internal Affairs and the National Police;

- programming environment, geoinformation monitoring, database management.

The training of specialists in criminal analysis involves teaching the subjects of specialization "Criminal Analysis", including: "Criminal Analysis", "Information Technologies", "Computer Networks and Telecommunication Technologies", "Information and Analytical Work in Operational and Investigative Activity" etc.

The training of specialists in criminal analysis is carried out in the following forms: lectures, seminars and practical classes, individual and independent work, practical training; the educational process combines both traditional and information technologies of learning.

During the training of criminal analysts, traditional (organization and implementation of educational and cognitive activities, stimulation of the motivation of educational activities, control, analysis and evaluation of learning outcomes) and innovative (problem education, multimedia lectures, business games, trainings, presentations, practice-oriented activities) teaching methods are used [13].

\subsection{System of professional training of specialists in criminal analysis}

An experience of the advanced countries all over the world is used for the training of criminal analysts of the National Police of Ukraine. Thus, the members of the Crime Analysis Unit of Romania, with support of EUAM, in February 2017 conducted a joint three weeks' analytical training for the staff of the National Police of Ukraine, National Anti-Corruption Bureau of Ukraine and lecturers of the National Academy of Internal Affairs [2].

In September-October 2017, Romanian specialists on the basis of the National Academy of Internal Affairs conducted a 20-day training course for the analysts of the departments of the criminal bloc of the National Police and the Criminal Analysis Department, as well as for the lecturers of higher education institutions of the Ministry of Internal Affairs of Ukraine, specialized in teaching criminal analysis, by use of the model "train of trainers".

The peculiarities of the training, on which the course of a criminal analysis is based, include the following:

1) the course starts from the very beginning;

2) ICT use;

3) emphasis on principles and techniques;

4) minimum of comments during the training;

5) encouragement of the activity of the participants of the training;

6) the course is based on practical exercises;

7) use of the formula "descriptiondemonstrationpractice-feedback";

8) practical testing.

Ultimately, trained analysts should help further advance of the ICT capacity building process by improvement of the police network, administering databases, information systems, data management, data quality control based on European ILP practices $[1 ; 3 ; 14]$.

According to the Standard of professional (professional and technical) education for the labor profession "police officer (for specialization)", approved by the Order of the Ministry of Education and Science of Ukraine dated June 21, 2018, No. 669, a curriculum for initial training of police officers specializing in "criminal police" in centers of primary training "Police Academy" was established.

The program includes training for police officers who were firstly appointed to the grade in the criminal police unit, and the discipline "Fundamentals of Criminal Analysis", which consists of the following issues: 
1. Criminal analysis: components of the process (collection, evaluation, data processing, logical justification).

2. Formation and evaluation of conclusions: logical, deductive and inductive matrices; practical approach to drawing conclusions.

3. Algorithm of drawing up of schemes of events, actions and analysis of telephone numbers.

The professional qualification program for criminal police officers based on the institutions of higher education of the Ministry of Internal Affairs of Ukraine also provides for the teaching of discipline "Criminal Analysis" for practical employees of the criminal investigation units, strategic investigations and combating illicit drug trafficking by the National Police of Ukraine.

One of the forms of an improvement of practical skills on the fundamentals of criminal analysis is the organization of traineeship of higher education graduates to expand the professional competencies of criminal analyst. Internship is conducted under the direction of scientific and pedagogical employees of the institutions of higher education of the Ministry of Internal Affairs and practical employees of criminal analysis units.

During practical training, cadets deepen their knowledge of operational, tactical and strategic analysis, risk analysis [15], analysis of information from open sources, master the analytical techniques of work with operational and statistical information, and get acquaintance with foreign experience of criminal analysis in law enforcement activities [16].

In the process of performing analytical and organizational-control functions, criminal analysts improve their training level.

Thus, the system of professional training of specialists in criminal analysis includes a complex of interrelated components (motivational, cognitive, organizational, methodological, professional), and envisages the gradual formation of the readiness of future criminal analysts for their professional activity at all the stages of their training.

\subsection{The main directions of using information and communication technologies in the training of specialists in criminal analysis}

An important factor in the training of specialists in criminal analysis is information technology education. Information technology teaching is a pedagogical technology that uses special methods, software and technical tools for handling with information; intended to create new opportunities for the transmission and perception of educational material, assessment of the quality of instruction and teaching [17, p. 83].
The use of teaching software in the context of ICT in the process of training future specialists in criminal analysis is carried out in the following areas: teacherconsultant, hypermedia training system, quasiteacher, virtual reality / virtual education environment.

In pedagogical science the importance of using computer-based learning tools is emphasized, which can implement software of educational activities of the applicants for higher education, help in the learning, develop thinking and creative activities. Computeroriented teaching tools are divided, in particular, into: reference and information; demonstration-simulation; aimed at the determination of the level of academic achievement; a knowledge acquisition, skills and abilities development; auxiliary computer-oriented tools [18, p. 36].

Information and education environment should be based on new technologies and provide educational process with electronic tools, electronic teaching and learning complexes, instructions on the use of various web and cloud services, broadband Internet, etc.

The use of ICT in the educational process can take place in a variety of organizational forms: online courses, online counseling, online trainings, hackathons, webinars, the use of interactive e-manuals, electronic virtual labs, electronic social networks, presentations, communication platforms for scientific interests, international contests for the solution of scientific and technical problems, virtual technology parks and others [19, p. 193-194].

One of the directions of using ICT in the training of specialists in criminal analysis is the creation of a virtual educational environment - an open system in which, based on the application of virtual reality technologies, effective interactive self-education in the educational process is provided. Virtual reality is a threedimensional computer space that can be investigated by a user. The introduction of ICT with the use of multimedia technologies and remote access to information and education resources in the training of criminal analysts contributes to a thorough continuity of virtual learning, and the selection of means and methods of learning contributes to the disclosure and identification of individual creative abilities of students (cadets) [20;21].

It should be noted that the creation of a virtual reality or a virtual educational environment is possible only in the institutions of higher education, where there is an expanded network of information provision that reflects the specificity and takes into account the peculiarities of the training of specialists in criminal analysis.

According to the results of the survey of criminal analysts of the National Police of Ukraine, the vast majority of respondents attributed to the main ways of the improvement of the training of future specialists in the criminal analysis with the use of ICT in the training of 
future specialists, in particular electronic tools $(75 \%)$, the introduction of e-learning courses $(68 \%)$, special computer programs and computer tests $(85 \%)$.

The use of ICT, in particular, e-manual or the implementation of the e-learning course, provides some opportunities in organizing the educational process of criminal analysts' training, namely:

- choice of the optimum rate of learning by the student (cadet);

- studying (learning) is carried out by such methods and at a level of complexity, which correspond most to the level of training and the individual characteristics of the student (cadet);

in the process of learning the student (cadet) may return to the information previously studied, obtain necessary advisory assistance, suspend learning process, and then return to it;

- listener (cadet) can observe the dynamics of various processes, the interaction of various mechanisms, guide the actions, processes, objects being studied;

- studying with e-manuals helps to overcome psychological barriers (indecision, fear of public speaking, language defects);

- provision of an access to unlimited amount of information.

The development of the LMS (Learning Management System) / learning management systems has expanded the use of e-learning content. The electronic training courses under the conditions of LMS systems are capable to provide the presentation of study material both in textual and audiovisual formats, and to provide an opportunity to guide learning [22, p. 36].

\section{CONCLUSIONS AND PROSPECTS FOR FURTHER RESEARCH}

The results of the study provide an opportunity to state that the priority areas for an improvement of the training of specialists in criminal analysis include: training for criminal analysts; use of ICT in the training of specialists in criminal analysis; improvement of the organization of an independent training of the specialists with the possibility of using Internet resources.

It is determined that information technology of teaching - innovative one, which involves the use of software and technical tools of work with information in the educational process, is an important factor in the training of specialists in criminal analysis.

The use of software tools in the context of ICT in the process of training of future specialists in criminal analysis is carried out in the following areas: teacher consultant, hypermedia training system, quasi-teacher, virtual reality / virtual education environment.
It is shown that the creation of a virtual educational environment is possible due to the presence of an extended network of information support, which reflects the specificity and takes into account the peculiarities of the training of specialists in criminal analysis under the conditions of the institution of higher education.

Generalization of the responses of the scientific and pedagogical staff of higher education institutions of the Ministry of Internal Affairs of Ukraine, according to the testing of the students (cadets), suggests that, on the basis of the results of the experimental use of ICT in the process of training of future specialists in criminal analysis, the level of their training increased, in particular the ability to:

- $\quad$ work with statistical data and their analysis;

- $\quad$ preparation of strategic assessments;

- $\quad$ SWOT, PESTLE / PEST analysis, situational and scenario analysis;

- $\quad$ search in open sources, detection, processing and analysis of an information;

- the use of analytical graphing visualization software and network associative lines, etc.

Priorities in the organization of training of specialists in criminal analysis in the centers of primary training "Police Academy" and higher education institutions of the Ministry of Internal Affairs of Ukraine should be: wide use in the educational process of computer-based tools and ICT, the practical implementation of distance learning technologies.

The prospects for further research are considered in the creation of a virtual educational environment for the training of specialists in criminal analysis for the units of the National Police of Ukraine in the institutions of higher education of the Ministry of Internal Affairs. In addition, it is envisaged to develop e-manuals and to implement an electronic training course "Criminal Analysis", as well as to identify the ways of introducing open distance courses into the training of specialists in criminal analysis.

\section{REFERENCES}

[1] Carter, J.G. Phillips, S.W. and Gayadeen, S.M. (2014), "Implementing Intelligence-Led Policing: An Application of Loose-Coupling Theory", Journal of Criminal Justice, No. 42, pp. 433-442. DOI: 10.1016/j/jcrimjus.2014.08.002

https://doi.org/:

[2] Intelligence-Led Policing: the cutting edge of modern law enforcement, available at: http://www.euam-ukraine.eu/news/opinion/ intelligence-led-policing-the-cutting-edgeofmodern-law-enforcement/ Accessed on: Feb. 23, 2017. 
[3] Korystin, O.YE. Peftiyev, D.O. Pen'kov, S.V. and Nekrasov, V.A. (2019), Dovidnyk kerivnyka politsiyi - politseys'ka diyal'nist', kerovana rozviduval'noyu analitykoyu /ILP [Police Chief's Directory - Intelligence-led policing / ILP], “ Vydavnytstvo Lyudmyla ”, Kyiv, Ukraina, 120 p.

[4] Movchan, A.V. and Taranukha, V.Yu. (2018), "Constructing an Automation System to Implement Intelligence-Led Policing Into the National Police of Ukraine", Cybernetic and System Analysis, vol. 54, No. 4, July, pp. 643-649. DOI: 10,1007/ s10559-018-0065-5

[5] Koval'chuk, T.I. Korystin, O.Ye. and Svyrydyuk, N.P. (2019), "Hybrid threats in the civil security sector in Ukraine", Nauka i pravooxorona, vol. 3 (45), pp. 69-79. DOI: doi.org/10.36486/np.2019308

[6] Police are working on a new system of criminal analysis, available at: http://old.kmu. gov.ua/kmu/control/publish/article?art_id=248764 635 (Accessed on: Jan. 15, 2019).

[7] In the training of future policemen, we must move to a new model of training, available at: https://www.npu.gov.ua/uk/publish/article/216828 3 (Accessed on: Jan. 05, 2019).

[8] Criminal analysis is an effective police work and citizen safety, available at: https://mvs.gov.ua/ua/news/10309_Kriminalniy_a naliz_ce_efektivna_robota_policii_ta_bezpeka_ gromadyan_FOTO.htm (Accessed on: Oct. 11, 2018).

[9] Salako, E.A. Adewale, O.S. and Boyinbode, O.K. (2019), “Appraisal on Perceived Multimedia Technologies as Modern Pedagogical Tools for Strategic Improvement on Teaching and Learning", I.J. Modern Education and Computer Science, No. 8, pp. 15-26. DOI: https://doi.org/10.5815 / ijmecs.2019.08.02.

[10] Liu, Y. and Zhang, X. (2020), "Evaluating the Undergraduate Course based on a Fuzzy AHP-FIS Model", I.J. Modern Education and Computer Science, vol. 12, No. 6, pp. 55-66. DOI: https://doi.org/10.5815 / ijmecs. 2020.06.05

[11] Khan, I.H. (2019), "Unified Framework for Systematic Evaluation of ABET Student Outcomes and Program Educational Objectives: I.J. Modern Education and Computer Science, vol. 11, No. 11, pp. 1-6. DOI: https://doi.org/10.5815 / ijmecs.2019.11.01

[12] Kremen, V.H. and Bykov, V.Yu. (2014), "Innovative tasks of the modern stage of informatization of education", Modern Information Technologies and Innovative Methods in the Training of Specialists: Methodology, Theory, Experience, Problems: save sciences works, vol. 37 / the editorial board: I.A. Ziaziun (head), Kyiv Vinnytsia: TOV "Planer", pp. 3-15.

[13] Movchan, A.V. (2018), "Model of training of specialists in the field of informational technologies for the National Police of Ukraine", Information Technologies and Learning Tools, No. 4, pp. 149161, available at: http://nbuv.gov.ua/UJRN/ITZN_2018_66_4_14

[14] S. De Matas and B.P. Keegan (2020), "A Case Study on Adult and Workplace Learning", I.J. Education and Management Engineering, vol. 10, No. 1, pp.11-19. DOI: https://doi.org/10.5815 / ijeme.2020.01.02

[15] Korystin, O.Ye. and Svyrydyuk, N.P. (2020), "Methodological principles of risk assessment in law enforcement activity", Nauka i pravooxorona, vol. 3, pp. 191-197. DOI: https: //doi.org/10.36486/np.2020.3(49).19

[16] Improvement of practical skills from the basics of criminal analysis, available at: https://www. naiau.kiev.ua/news/udoskonalennyapraktichnihnavikiv-z-osnov-kriminalnogoanalizu.html (Accessed on: Jan. 30, 2019).

[17] Tsyirkun, I.I. (2010), Pedagogical systems and technologies: laboratory workshop: teaching aid, Minsk: Tetra Sistems, 224 p.

[18] Koval, T.I. (2011), "Interactive technologies of teaching foreign languages in higher educational institutions", Information Technologies and Learning Tools, No. 6 (26), available at: http://www.journal.iitta.gov.ua (Accessed on: Jan. 30, 2019).

[19] Bykov, V. Spirin, O. and Pinchuk, O. (2017). "Problems and tasks of the modern stage of education informatization", Scientific support for the development of education in Ukraine: actual problems of theory and practice (up to the 25th anniversary of the National Academy of Sciences of Ukraine). Publishing house "Sam". pp. 191-198.

[20] Hrybiuk, O.O. "A virtual educational environment as an innovative resource for students' learning and research", available at: http://www.lib.iitta.gov.ua/Grybyuk-tezy.pdf (Accessed on: Jan. 30, 2019).

[21] Trigui, M.S. and Alghazzawi, D.M. (2012), "Learning the Related Mathematics to Cryptography by Interactive Way", I.J. Modern 
Education and Computer Science, vol. 4, No. 2, pp. 814. DOI: https://doi.org/10.5815/ijmecs. 2012.02.02
[22] Batsurovska, I.V. (2016), Educational and scientific preparation of masters in conditions of mass distance courses, monograph, Hrin D.S., Kherson, Ukrain, $514 \mathrm{p}$. 